is far from satistactory. The meiotic manœuvres are, of course, meaningless unless related to allelic segregation. As such the second meiotic division is no less significant than the first. Reduction is not a consequence of either meiotic division alone; a given locus may show qualitative segregation at either first or second division. Indeed different elements in the same chromosome will behave differently in this respect as too may the same element in different cells. But who would have guessed this from the claim (p. 7) that " the first division has been designated the reductional division because it reduces the chromosome number and the second division is called equational and is apparently mitotic". And who would argue with the reviewer for concluding that the author himself was oblivious of the truth. Having failed with normal meiosis Professor Bacci, not unnaturally, is subsequently overwhelmed when he deals with parthenogenesis.

Of the other genetical inadequacies there are those which border on the respectable in the sense that they have been made recurrently by some of our leading biologists. Thus Professor Bacci is certainly not the first to fail to draw accurately, let alone appreciate the meaning of, a chiasma (fig. I $3 c$ and $d$, p. 8). Neither is he the first to fail to draw the line between sexuality and incompatibility (chap. 3). Finally, and in a lighter vein, the catholic tastes of the author in genetical theory are emphasised by his comparison between chromomeres and the "beads of a rosary" (p. 7) -to which one is tempted to add "string without end: amen!" His analogy should certainly commend itself to those who in their search for linkage relationships among microbes find themselves going round in perpetual circles.

The second source of difficulty in overcoming the factual constipation inherent in a diet of sex is by no means peculiar to Professor Bacci. It is one which has long bedevilled the whole issue: namely, the pseudo-quantitative use of a system of $\mathrm{M}$ and $\mathrm{F}$ factors fostered first by Richard Goldschmidt. This has always been too lax a laxative and in adopting it the author, like many who have preceded him, has tended to prolong the disorder rather than relieve it.

On the credit side, however, the book brings to our attention a whole host of problems which have too long been neglected by developmental and population geneticists. In the past these problems have too often been the domain of traditionally minded botanists and zoologists. In their hands there has been a lengthy and unhappy history of dealing with problems descriptively rather than analytically. This has led to the assembly of a vast collection of terms which have tended to confuse both the problem and the student. In perpetuating these terms, and the attitudes which fostered them, Professor Bacci runs the risk of confusing those who choose to give, or can only give, his book a superficial reading. And the plain fact is that, on account of the shallow explanations offered, it is considerably easier to read this book superficially than with depth.

B. JoHN.

\title{
THE CYTOLOGY OF THE BED BUG
}

MONOGRAPH OF CIMICIDA (HEMIPTERA-HOMOPTERA). Robert L. Usinger. Published by the Entomological Society of America, College Park, Maryland, 1966. Pp. $x i+585$. $\$ 10.00$.

Since the initial studies of Slack and Darlington geneticists and cytologists have been interested in the chromosome systems of the bed bug. 
Chromosome studies have been included in Usinger's long-term research programme on the bed bugs and are reported here in chapters by Ueshima and McKean. The monograph includes much of what is known about the biology of the insects including topics of applied interest such as control and disease transmission. No geneticist would doubt that the cytology and cytogenetics of a group of organisms represents one of their most fundamental attributes. Neither is there question about the great usefulness of having most of what is known about a group of organisms neatly reviewed between two covers. Correlations between ecology, life cycle and genetic system, taxonomonic status and chromosome number and so on become readily apparent. There is always the danger, however, that such information will be missed by those not directly concerned with the group reviewed.

Ueshima describes the chromosomal cytology of over thirty species from nineteen genera and six subfamilies; his work is illustrated with over two hundred and fifty beautiful photographs and drawings fully verifying his descriptions. Haploid numbers of autosomes range from 4 to 18 and the sex chromosome garniture in the male ranges from XY to $9 \mathrm{X}$ 's and a $\mathrm{Y}$. In addition to the reports on the species and their taxonomic relationships, Ueshima's chapter includes details of numerous hybridisation experiments. The most important results from the latter are the clear demonstrations of co-orientation and reductional separation of the bivalents at anaphase I and the appearance of unexpected heterochromatic elements at prophase I.

Of special interest is the exhaustive analysis of the control of the number of $\mathrm{X}$ chromosomes in strains of Cimex lectularius and C. columbarius. Crosses and backcrosses were maintained for four generations in extensively replicated series. An analysis of the results by McKean indicates no simple explanation. The number of supernumerary X's may be determined by the cytoplasm or by factors on the $\mathrm{X}$ chromosomes themselves or by some combination of these and other factors.

In conclusion, this work should not be overlooked by anyone interested in the evolution of chromosome systems.

Spencer W. Brown.

\section{BOOKS RECEIVED}

THE CHROMOSOMES OF THE ALGA. Maud B. E. Godward. Edward Arnold Ltd., London, 1966. Pp. 212. 55s.

DEVELOPMENTAL GENETICS. Frederick J. Gottlieb. Chapman and Hall Ltd., London, 1966. Pp. 118. 10s. 6d.

THE BIOCHEMICAL GENETICS OF VERTEBRATES EXCEPT MAN. I. E. Lush. North Holland Publishing Company, Amsterdam, 1966. Pp. 118. 36s.

PROTEIN BIOSYNTHESIS AND PROBLEMS OF HEREDITY, DEVELOPMENT AND AGEING. Zhores A. Medvedev. Oliver and Boyd Ltd., Edinburgh, 1966. Pp. 584. $65,10 \mathrm{~s}$.

MODERN GENETICS 2. J. A. Serra. Academic Press Inc., London, 1966. Pp. 616. 135s. GENETIK UND ZYTOLOGIE VON ANTIRRHINUM L. SECT. ANTIRRHINUM. Hans Stubbe. Veb Gustav Fischer Verlag, Jena, 1966. Pp. 421. £7, 5 s.

RESEARCH ON GENETICS IN PSYCHIATRY. W.H.O. Technical Report Series No. 346. Geneva, 1966. Pp. 20. 3s. 6d.

CONGENITAL MALFORMATIONS. A Report of a Study of Series of Consecutive Births in 24 Centres. W.H.O., Geneva, 1966. Pp. 127.12 s.

GENETICS. 3rd Edition. A. M. Winchester. Constable \& Co. Ltd., London, 1966. Pp. 504. 60s.

HAMOGLOBINOPATHIES AND ALLIED DISORDERS. Report of a W.H.O. Scientific Group. W.H.O. Technical Report Series No. 338. Geneva, 1966. Pp. 40 . $5 \mathrm{~s}$. 